ing government, political science, public administration, or international relations in institutions with chapters are also eligible for membership.

Membership in the society may also be secured through election as an honorary member. Only distinguished persons who have made valuable contributions to political science or government are eligible for election into honorary membership.

It is the aim of Pi Sigma Alpha to be much more than a group of chapters devoted solely to the election of honor students into membership. Each chapter is encouraged to be a working organization throughout the academic year, functioning as an integral part of the political science department in the promotion of worthwhile extracurricular activities related to public affairs and scholarship in our field.

Pi Sigma Alpha promises to continue to serve the objectives stated in its constitution-"to stimulate productive scholarship and intelligent interest in the subject of government.
Pi Sigma Alpha assists in the establishment of new chapters in colleges or universities where the organization of a chapter would be mutually advantageous to the society and to the institution. Additional information concerning the procedure in petitioning for a chapter is available upon request to the national office.

A local chapter may be established at any college or university granting the baccalaureate degree or higher degrees, which is accredited by a regional or national accrediting association whose accreditation is acceptable to the Executive Council. The institution must offer a major sequence of courses in government, political science, international relations, or public administration through an appropriate administrative department or school, and must meet certain requirements as to faculty, enrollment, and autonomy. Detailed criteria are available from the Pi Sigma Alpha National Office, address below. Final decision regarding the admission of a petitioning group rests with the society's council and the member chapters.

There is no one type of institution in which the society functions best. The organization is such that highly successful chapters are maintained in many sizes and varieties of colleges and universities. Some chapters have conducted worthwhile and active programs with only a dozen active student members at any one time; others have several times this number of active members.

For information regarding the establishment of a chapter of $\mathrm{Pi}$ Sigma Alpha, please write to: $\mathrm{Pi}$ Sigma Alpha National Office, 1527 New Hampshire Avenue, N.W., Washington, DC 20036.

\section{About the Author}

Charles Tidmarch is professor of political science, Union Coliege, Schenectady, New York, and editor of Pi Sigma Alpha Newsletter.

\title{
Five New Course Syllabi Collections Just Published
}

\begin{abstract}
The APSA has just published the second set of five syllabi collections for political science courses, in the final year of a project supported by a grant from the Fund for the Improvement of Postsecondary Education. The project is intended to assist faculty and advanced graduate students in planning and revising syllabi for their undergraduate courses. Each collection contains around a dozen syllabi selected by an editor from a large number of submissions. The selected syllabi exemplify different approaches to the course topics as well as different institutional contexts and instructional strategies. An essay by the editor introduces syllabi in each collection with a commentary on the objectives of the particular course.

A list of the titles, editors, and
\end{abstract}

contributors to each of these new collections follows:

\section{Public Law-Edited by Lief $\mathrm{H}$.} Carter, University of Georgia.

The contributors are: Richard A. Brisbin, West Virginia University; William K. Muir, University of California-Berkeley; John E. Finn, Wesleyan University; Ron Christenson, Gustavus Adolphus College; Timothy J. O'Neill, Southwestern University; William Haltom, University of Puget Sound; David M. O'Brien, Princeton University; Herbert Kritzer, University of Wisconsin; Roy B. Flemming, Texas A\&M University; and Kim Lane Scheppele, University of Michigan.

This collection also contains excerpts from the syllabi of: Walter
Murphy, Princeton University; Leslie Goldstein, University of Delaware; Albert R. Matheny, University of Florida; David Barnum, De Paul University; Larry Baum, Ohio State University; Nancy Kassop, State University of New York-New Paltz; James Foster, Oregon State University; Dalmas H. Nelson, University of Utah; Grier Stephenson, Franklin and Marshall College; Tom Hensley, Kent State University; Stephen L. Wasby, State University of New York-Albany; Burton Atkins, Florida State University; Gerald Rosenberg, University of Chicago; Susan Olson, University of Utah; John Mueller, Luther College; Francis Graham Lee, St. Joseph's University; Mark Kessler, Bates College; Diane E. Wall, Mississippi State University. 


\section{AMERICAN POLITICAL SCIENCE ASSOCIATION}

\section{THE POLITICAL SCIENCE COURSE SYLLABI COLLECTION ORDER FORM}

The Course Syllabi Project has developed selected collections of exemplary syllabi for reference and adaption by departments, faculty and graduate students in designing courses. If you are planning a new course, revising a current course, or adding a course to your undergraduate curriculm, the collections of course syllabi edited by experienced faculty provide valuable guidance and references.

\section{Introductory/Survey Courses}

- Introduction to International Relations, edited by Linda Brady, Georgia Inst. of Technology

- American Government and Politics, edited by Marjorie R. Hershey, Indiana University

- Introduction to Political Theory, edited by Peter G. Stillman, Vassar College

- Introduction to Political Science, edited by John C. Wahlke, University of Arizona

- Comparative Government and Politics, edited by Frank L. Wilson, Purdue University

\section{Advanced/Upper Division Courses}

- Public Law, edited by Leif $H$. Carter, University of Georgia

- Methodology, edited by John R. Freeman and W. Phillips Shively, University of Minnesota

- Capstone Course/Senior Seminar, edited by Ronald Kahn, Oberlin College

- $\quad$ Public Administration, edited by Naomi Lynn, Sangamon State University

- Political Behavior, edited by Nancy H. Zingale, College of St. Thomas

* Indicate the titles and number of copies desired

* The Syllabi are \$5.00 EACH. Orders must be PREPAID.

* Visa/Mastercard accepted. Orders shipped via regular UPS.

Name (please print clearly)

\begin{tabular}{|c|c|c|c|c|c|}
\hline Address & & & City & State & $\overline{Z i p}$ \\
\hline Method of Payment: & _Check & _Visa & _Mastercard & & \\
\hline
\end{tabular}

Signature

Send to: APSA Publications, 1527 New Hampshire Avenue, NW Washington, DC 20036

Phone: (202) 483-2512 Fax (202) 483-2657 


\title{
Reaching Those Who Teach Teachers: \\ Defining the Core of Constitutionalism, Citizenship, and Civic Education \\ An NEH Summer Institute for College and University Faculty \\ June 13-July 15, 1993 \\ University of Tulsa
}

The summer institute, a project of the American Political Science Association and the University of Tulsa, is supported by a major grant from the National Endowment for the Humanities.

\section{The Program}

The summer institute is an innovative effort to tackle the problem of how to enhance the quality of teaching about constitutionalism, constitutional history, civic education, and citizenship for college students who will enter the ranks of the teaching profession. Seminar topics include: "The Nature of American Constitutionalism," "The Colonial and Early American Background of the Constitutions and the Bills of Rights," "The Scope of Individual Rights," "The Guarantees of Equal Rights and Liberties to All Americans," and such other topics as freedom of expression and separation of church and state. The institute addresses these topics by concentrating on both content and pedagogy, exploring the various ways in which the central messages of the history of the Constitution and constitutionalism can be most effectively presented in order to heighten understanding about citizenship.

\section{The Faculty}

\author{
Institute Director: \\ Kermit L. Hall \\ Dean, Henry Kendall College \\ University of Tulsa
}

Guest Faculty:

Herman Belz, University of Maryland

Lief H. Carter, University of Georgia

Donald S. Lutz, University of Houston

Sandra F. VanBurkleo, Wayne State University

\section{Participant Eligibility}

The institute seeks applications from teams of college faculty drawn from history, political science, and social studies education. Each team should include two persons, one of whom must be a social studies education professor accompanied either by a historian or political scientist from the same institution. The faculty teams will be responsible for developing and coordinating the content and methodology of courses designed in their institutions to prepare pre-collegiate teachers to teach American history, civics, and government.

\section{Participant Stipends}

Participants will receive funds for travel to and from the institute, for room and board, and a stipend of $\$ 1,125$.

\section{Application Procedures}

Faculty applying should do so as a team by sending a joint letter of application accompanied by each applicant's resume. The letter should indicate which courses offered by the faculty are required or recommended to students who will be teachers and how the faculty believe the institute can contribute to the design of courses and to coordinating teacher training.

Application deadline is March 1, 1993.

Applications and inquiries should be directed to: Summer Institute/Constitutionalism, APSA, 1527 New Hampshire Ave., NW, Washington, DC 20036. Fax: (202) 483-2657. Telephone: (202) 483-2512. 
Methodology-Edited by John R. Freeman and $\mathrm{W}$. Phillips Shively, University of Minnesota.

The contributors are: Davida J. Alperin, University of WisconsinRiver Falls; Stephen Barton, San Francisco State University; Donald M. Freeman, University of Evansville; Kenneth Janda, Northwestern University; Paul E. Johnson, University of Kansas; George E. Marcus, Williams College; John Sprague, Washington University; Edward Tufte, Yale University; and Myron Weiner, Massachusetts Institute of Technology.

Capstone Course/Senior SeminarEdited by Ronald Kahn, Oberlin College.

The contributors are: Timothy $\mathrm{V}$. Kaufman-Osborn, Whitman College; Joan Hulse Thompson, Beaver College; Timothy J. O'Neill, Southwestern University; Marilyn A. Davis, Spelman College; Tom Kazee, Davidson College; Barbara Welling Hall,
Earlham College; Chip Hauss, Colby College; Michael Kraft, University of Wisconsin-Green Bay; Ray Hopkins, Swarthmore College; and Larry Caldwell, Occidental College.

Public Administration-Edited by Naomi B. Lynn, Sangamon State University.

The contributors are: Harvey Lieber, American University; John Rouse, Ball State University; Clifford O. Young, California State University-San Bernardino; David K. Leonard with Peter Houtzager, University of California-Berkeley; Jane Fountain, Harvard University; Manindra K. Mohapatra, Indiana State University; George Frederickson, University of Kansas; Ellis Perlman, University of Michigan-Flint; Joseph P. Viteritti, New York University; Marilyn A. Davis, Spelman College; Kal Kayali, Suffolk University; Anne M. Khademian, University of Wisconsin-Madison; Roger Printup, University of Virginia; and
Gary L. Wamsley, Virginia Polytechnic Institute and State University.

Political Behavior-Edited by Nancy $\mathrm{H}$. Zingale, University of St.

Thomas.

The contributors are: David C. Leege, University of Notre Dame; Charles Prysby, University of North Carolina-Greensboro; Kristi Andersen, Syracuse University; George Marcus, Williams College; Leonie Huddy, State University of New York-Stony Brook; John Sullivan, University of Minnesota; Russell Dalton, University of CaliforniaIrvine; Lawrence LeDuc, University of Toronto; and Martha Ackelsberg, Smith College.

Information about ordering these syllabi collections and the five collections for the introductory courses on Political Science, American Government and Politics, Comparative Government and Politics, International Relations, and Political Theory can be found on page 711 of this issue of $P S$.

\title{
IF YOU NEED TO WRITE, CALL, OR FAX A DEPARTMENT OF POLITICAL SCIENCE --
}

\begin{abstract}
APSA's newly revised 1992-93 Directory of Political Science Department Chairpersons alphabetically lists all departments in the United States with current chair names, department addresses, telephone and fax numbers. Highest degree offered is also indicated for each department.
\end{abstract}

The cost is $\$ 20+\$ 3.50$ postage for APSA members, $\$ 25+\$ 3.50$ postage for nonmembers.

The Directory is also available on mailing labels. Departments that are members of the Departmental Services Program pay $\$ 75$ for the total list. All other orders pay $\$ 175$.

Order from: APSA Publications, 1527 New Hampshire Avenue, NW Washington DC 20036

ORDERS MUST BE PREPAID

Mastercard and Visa accepted 